\title{
Transparent exopolymer particle (TEP) dynamics in relation to trophic and hydrological conditions in the NW Mediterranean Sea
}

\author{
S. Beauvais, M. L. Pedrotti* ${ }^{*}$ E. Villa, R. Lemée \\ Marine Microbial Ecology Group, LOV, UMR 7093-CNRS, Observatoire Océanologique, BP 28, \\ Villefranche-sur-Mer 06234 Cedex, France
}

\begin{abstract}
Seasonal abundance, volume, size distribution and carbon content of transparent exopolymeric particles (TEP) were examined in 2 hydrologically distinct sites in the NW Mediterranean (NWM) Sea: a coastal (Point B, Villefranche Bay) and an offshore (DYFAMED, France, JGOFS) site. TEP concentration varied from 0.2 to $2.2 \times 10^{5}$ particles $\mathrm{ml}^{-1}$, and was higher offshore. The TEP pool was low during the winter mesotrophic period and increased after the spring bloom, remaining relatively high throughout summer at both sites. The increase in TEP abundance during the oligotrophic period was relatable to nitrate limitation and a decline in primary production. TEP formation in spring was associated to a nanoflagellate bloom, while the build-up of a large pool of TEP in summer occurred in the presence of a phytoplankton community dominated by picoplankters and during strong thermal stratification, limiting vertical sedimentation. In the NWM Sea, when the TEP carbon pool (TEP-C) is high, it may represent up to $22 \%$ of the total organic carbon, and reach down to $1 \%$ when it is low, suggesting that the particles play a significant role in the carbon cycle. In the NWM Sea, the trophic status of the system and the composition of primary producers control TEP formation. Hydrological processes appear to be of primary importance in governing seasonal TEP distribution.
\end{abstract}

KEY WORDS: Transparent exopolymer particles · TEP · POC $\cdot$ DOC $\cdot$ Oligotrophy $\cdot$ Hydrological processes Resale or republication not permitted without written consent of the publisher

\section{INTRODUCTION}

Transparent exopolymeric particles (TEP) are formed abiotically by spontaneous coagulation of the colloidal fraction of dissolved organic polysaccharides, substances exuded by phytoplankton and bacteria (Alldredge et al. 1993, Passow \& Alldredge 1994). These non-living organic particles are flexible, transparent and fragile, and thus estimating their concentration requires specialized techniques. Although there are difficulties in comparing TEP concentrations when different data collection methods are used, the particles appear to be ubiquitous in the oceans (Passow \& Alldredge 1994, Mari \& KiØrboe 1996, Ramaiah et al. 2001) as well as in freshwaters (Grossart et al. 1997).
TEP have received a great deal of attention over the past $10 \mathrm{yr}$ (Alldredge et al. 1993, Schuster \& Herndl 1995, Engel \& Passow 2001), testifying to their potential importance in several biogeochemical processes. TEP form the organic matrix of marine snow, enhancing vertical fluxes of organic matter (Smetacek 1985, Passow et al. 2001) and carbon export from the surface ocean (Fowler \& Knauer 1986, Engel 2002). Due to their high stickiness, these particles aggregate with each other and with detritus (Kiørboe \& Hansen 1993), leading to flocculation and sedimentation of non-living matter. Moreover, TEP and derived aggregates serve as substratum and microhabitats for attached bacteria (Passow \& Alldredge 1994, Mari \& Kiørboe 1996) and could be a direct source of carbon for higher trophic levels via protists, microzooplankton and even nekton, 
such as larval fish (Grossart et al. 1998, Passow \& Alldredge 1999). If TEP are consumed, they represent a direct transfer of energy from dissolved matter to higher trophic levels, shunting the microbial loop. While the role played by TEP in the cycling of carbon is not under doubt, the importance of this role is uncertain. Consequently, knowledge concerning the occurrence and abundance of TEP in the field is of primary importance to correctly assess the relative importance of different stocks and fluxes of carbon in the pelagic ecosystem.

In the NW Mediterranean (NWM) Sea, at a French JGOFS time-series station (DYFAMED), Mari et al. (2001) showed that the formation of a carbon-rich TEP pool with a high C:N ratio could explain the carbon over-consumption observed in this area (CopinMontégut \& Avril 1993). In this paper we report the seasonal distribution of TEP in this offshore station, and we compare the temporal distribution patterns with a coastal site (Point B, Villefranche Bay) in the same area. There are few annual surveys of TEP distribution, especially in a meso-oligothophic area such as that of the NWM Sea (see review of Passow 2002).

The aims of this study were to (1) describe the seasonal variability in abundance and characteristics (size frequency, $\mathrm{C}: \mathrm{N}$ ratio and carbon content) of TEP, and relate this variability to hydrological conditions and the prevailing status of 2 meso-oligothophic systems; and (2) evaluate the TEP pool in relation to other organic carbon pools at DYFAMED in order to assess the potential importance of TEP in the carbon cycle.

\section{MATERIALS AND METHODS}

Study sites. This study was carried out in the NWM Sea (Fig. 1) from February 1999 to February 2000 at 2 sites: (1) Point B ( $\left.43^{\circ} 41^{\prime} 10^{\prime \prime} \mathrm{N}, 07^{\circ} 19^{\prime} 0^{\prime \prime} \mathrm{E}\right)$, in the coastal zone located at the entrance of Villefranche Bay and influenced by the Liguro-Provençal current, resulting in continual water renewal (Nival \& Corre 1976). The Bay is subject to the influence of a cyclonic current running from east to west along the French Riviera. In normal conditions, a branch of the Ligurian Current flowing westward offshore enters the Bay. Near the coast, the average water speed in the surface layer can reach $20 \mathrm{~cm} \mathrm{~s}^{-1}$ (Béthoux et al. 1988); and (2) DYFAMED $\left(43^{\circ} 25^{\prime} 2^{\prime \prime} N, 07^{\circ} 51^{\prime} 8^{\prime \prime} \mathrm{E}\right)$, an offshore site where seasonal hydrological features are well documented, as it is a French JGOFS time-series station. The DYFAMED station, located in the central part of the Ligurian Sea, is predominantly influenced by vertical advection and is considered as an oceanic site. At DYFAMED, maximal winter-downwelling speed is ca. 10 to $15 \mathrm{~cm} \mathrm{~s}^{-1}$, while the speed during the stratification period is ca. $0.2 \mathrm{~cm} \mathrm{~s}^{-1}$ (Béthoux \& Prieur 1983). Horizontal water fluxes could be neglected due to cyclonic circulation and the Ligurian frontal system that acts as a physical barrier (Béthoux et al. 1988, Sournia et al. 1990). Advection is very weak, and the current speed $\left(3 \mathrm{~cm} \mathrm{~s}^{-1}\right)$ is generally below the minimum detectable level of current meters (Andersen \& Prieur 2000).

Sampling. Water samples for TEP analysis were collected monthly using an acid-washed 301 Niskin bottle (General Oceanics) at the depth of the chlorophyll maximum (DCM) layer previously determined by a flu-

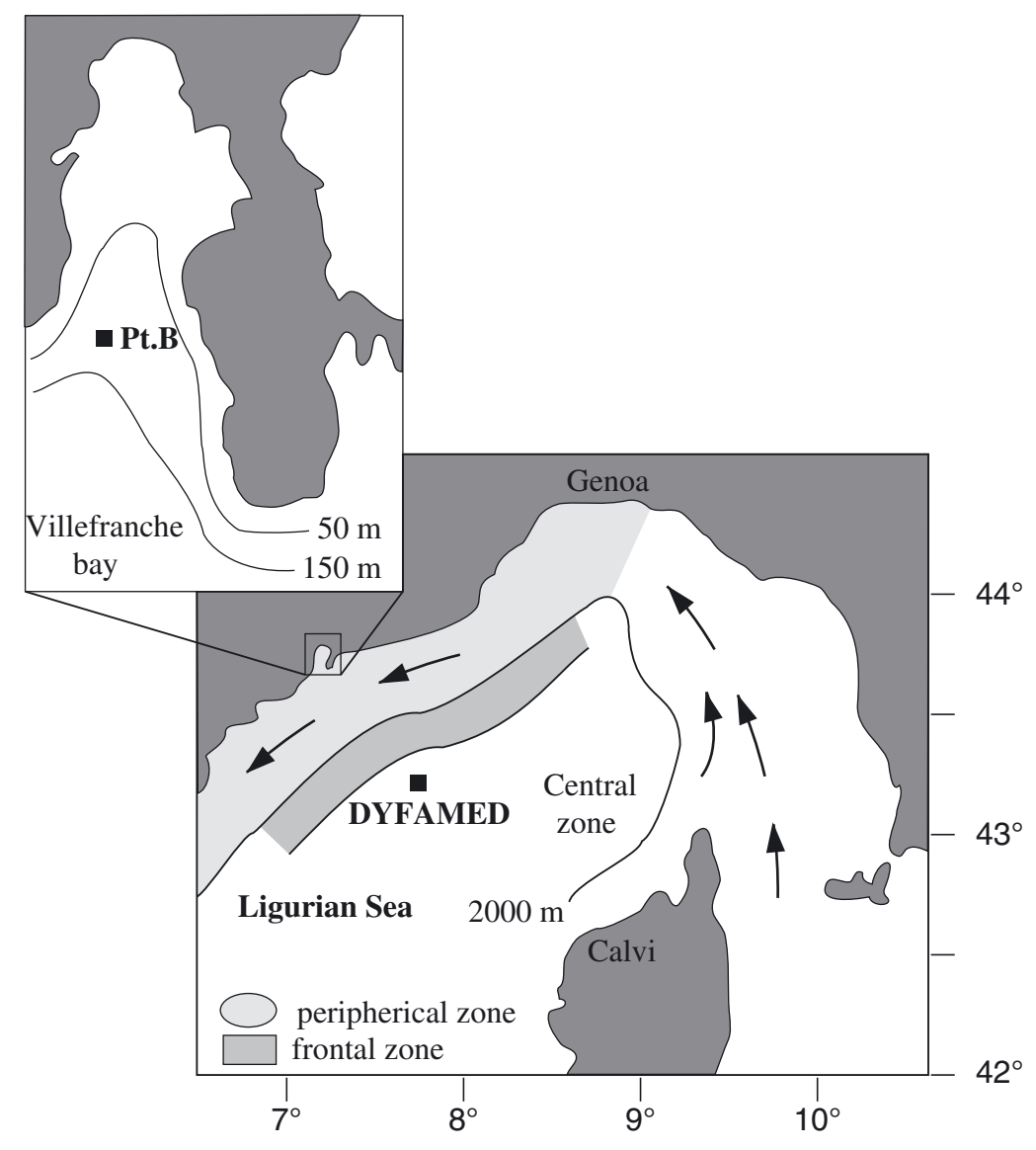

Fig. 1. Location of sampling sites. DYFAMED, the open-sea site in the central zone of the Ligurian sea, and Point B (Pt.B), at the entrance of Villefranche Bay (France). Arrows represent the Ligurian Current 
orimeter coupled with a CTD Seabird (SBE 25) probe. CTD casts were used on each sampling date to describe the vertical stratification of physical and chemical parameters. Depths of sampling for pigment and nutrient analysis were 5, 10, 30, 50 and $75 \mathrm{~m}$ at Point B and 5, 10, 20, 30, 40, 50, 70, 80, 110 and $130 \mathrm{~m}$ at DYFAMED. Nitrate and phosphate concentrations were determined using an autoanalyzer, according to the Tréguer \& Le Corre (1975) method. Chl a concentrations were measured at Point B by spectrophotometry, and at DYFAMED by HPLC, following the method of Vidussi et al. (1996). Primary production (PP) was determined by in situ ${ }^{14} \mathrm{C}$-bicarbonate incorporation according to Dandonneau \& Le Bouteiller (1992). The correction factor described by Moutin et al. (1999) was used to convert PP rates obtained during the $4 \mathrm{~h}$ incubations to daily $(24 \mathrm{~h})$ rates. Data of PP

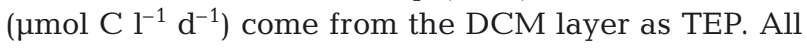
samples for TEP analysis were prepared fresh, on board, within the $2 \mathrm{~h}$ following sampling.

Staining procedure and enumeration of TEP. TEP were studied following the method of Passow \& Alldredge (1994). Several seawater aliquots (5, 10 and 15 $\mathrm{ml}$ ) were gently filtered through $0.2 \mu \mathrm{m}$ Nuclepore ${ }^{\mathrm{TM}}$ filters under constant low pressure. TEP retained on the filter were stained with $500 \mu \mathrm{l}$ of a solution of $0.06 \%$ acetic acid (pH 2.5) and $0.02 \%$ Alcian blue 8GX (Hopkin \& William). Since Alcian blue, a specific stain for negatively charged polysaccharides, may precipitate in the presence of salts, it may produce artifacts that could be mistaken as TEP. To avoid this occurring, materials were rinsed with distilled water between consecutive filtrations, and the dye was tested before each experiment with artificial seawater at 38.2\% (SIGMA), twice filtered onto a $0.2 \mu \mathrm{m}$ filter. Blanks didn't show a significant presence of TEP. After the staining procedure, TEP were transferred to a microscope slide using the filter-transfer-freeze technique (Hewes \& Holm-Hansen 1983). During winter 1999/ 2000, filters containing TEP were also mounted directly on a white slide (Cyto-Clear $\left.{ }^{\circledR}\right)$, providing direct observations of TEP (Logan et al. 1994).

TEP were observed through an Axiophot-Zeiss microscope. Pictures were captured with a CCD colour video camera (COHU 2252-1040, $752 \times 582$ pixel resolution, 0.08 lux minimum sensitivity). TEP were counted using Image Pro Plus 4 software. A minimum of 600 TEP were counted and sized at 3 successive magnifications $(100 \times, 200 \times, 400 \times)$, in order to better cover the entire size spectra (Mari \& Burd 1998). The equivalent spherical diameter (ESD) of each TEP was calculated from the measurement of its cross-sectional area by means of a semi-automatic image-analysis system. Counts were classified, according to their ESD, into 15 logarithmic size classes between 1 and $135 \mu \mathrm{m}$.
Size distribution and TEP volume. TEP size distribution follows a classical power law usually used to describe the distribution of ocean particles (Sheldon et al. 1972), which is defined by the equation from McCave (1984):

$$
d N / d\left(d_{\mathrm{p}}\right)=\mathrm{k} d_{\mathrm{p}}^{\delta}
$$

where $d N$ is the number of particles per unit volume, with a diameter ranging from $d_{\mathrm{p}}$ to $\left[d_{\mathrm{p}}+d\left(d_{\mathrm{p}}\right)\right]$, with $d_{\mathrm{p}}$ being the projected spherical encased diameter. The constant $\mathrm{k}$ depends on particle concentration, and the slope $\delta$ gives indications about the abundance of small particles relative to those of larger ones. $\mathrm{k}$ and $\delta$ were calculated using linear regression of $\log \left[d N / d\left(d_{\mathrm{p}}\right)\right]$ versus $\log \left(d_{\mathrm{p}}\right)$. Differences between the slopes of regression lines were statistically compared using analysis of covariance (ANCOVA), performed using SYSTAT software. Application conditions (normality of residuals, homoscedasticity and linearity) were also tested to ensure that they conformed to the assumptions of parametric statistics: no transformations were required. The number of TEP $\mathrm{ml}^{-1}$ was normalized by the length of the considered size class $(\mu \mathrm{m})$. TEP volume concentrations are given in ppm.

TEP carbon and nitrogen measurements. In the sea, TEP are associated with the other suspended particles (phytoplankton cells, detritus, etc.) in the same size ranges, which make separate chemical analysis impossible. To estimate the TEP C:N ratio of Point B samples, TEP were produced by bubbling their precursors (high molecular-weight dissolved organic matter) from GF/C-filtered water. This method accelerates TEP formation, allows their isolation, and finally permits their chemical characterization (Mari 1999). After bubbling, TEP samples were collected onto GF/F filters (nominal pore size $0.7 \mu \mathrm{m}$ ) for carbon and nitrogen determinations. The experimental protocol is detailed, and the filtration steps are justified in Mari et al. (2001).

Estimation of organic carbon pools: TEP, dissolved organic carbon (DOC), particulate organic carbon (POC) and phytoplankton. TEP are fractal aggregates (Alldredge et al. 1993). As is typical of fractal structures, their porosity increases with increasing aggregate size, resulting in reduced mass per unit volume as the particles get larger. TEP carbon content is then linked to the size of the considered particle. In our study, it was determined from the size frequencydistribution of TEP sampled in situ using the sizedependent relationship proposed by Mari (1999):

$$
\text { TEP-C }=0.25 \sum_{\mathrm{i}} n_{\mathrm{i}} r_{\mathrm{i}}^{2.55}
$$

where TEP-C is given in $\mu \mathrm{g} \mathrm{C} \mathrm{ml}^{-1}, n_{\mathrm{i}}$ is the concentration of particles in size class $s_{i}$, and $r_{\mathrm{i}}$ is the TEP radius $(\mu \mathrm{m})$ in the same size class. 
We compared TEP-C to other organic carbon reservoirs at the depth of the DCM at DYFAMED. Data of DOC come from Avril (2002). As DOC is conservative for this area, the DOC dataset is the result of a composite annual-cycle average-distribution over 40 monthly profiles. Data of POC were obtained from the JGOFS database. They come from the same samplings dates as the TEP. Concentrations were determined by high-temperature oxidation using a Heroes CHN-ORapid analyzer (Miquel et al. 1994). The portion of organic carbon linked to phytoplankton (C-phytoplankton) was determined by plotting POC data ( $\mu \mathrm{g}$ $\mathrm{l}^{-1}$ ) against chl a data (mg m${ }^{-3}$ ) (Marty et al. 2002). Total data of POC, DOC, primary production and chl a concentrations are available from the JGOFS-France database, available at www.obs-vlfr.fr/jgofs/html/ bdjgofs.html.

\section{RESULTS}

\section{Hydrological features}

\section{DYFAMED site}

In winter, due to strong vertical mixing, temperature was homogeneous with depth $\left(13^{\circ} \mathrm{C}\right)$ to $200 \mathrm{~m}$. In summer, the water column was well stratified with a marked pycno- and thermocline between 20 and $45 \mathrm{~m}$ that isolated surface waters from the deeper waters. The transition between mixed and stratified periods occurred during spring and early winter (Fig. 2a). The winter period was relatively rich in nutrients (with nitrate and phosphate concentrations of 3 to 4 and 0.15 to $0.20 \mu \mathrm{mol} \mathrm{l}^{-1}$, respectively) in the surface layer. From April to late autumn, surface water became depleted in nutrients, the nitrate concentration decreased to below $0.5 \mu \mathrm{mol} \mathrm{l}^{-1}$ (Fig. 2c), and phosphates reached undetectable levels. The seasonal distribution of chl a (Fig. 2e) was characterized by a first phytoplankton bloom $\left(2.9 \mu \mathrm{g} \mathrm{chl} \mathrm{a}^{-1}\right)$ at the beginning of March in the surface mixed layer, and a second one in June on the pycnocline layer (up to $1.2 \mu \mathrm{g} \mathrm{chl} \mathrm{a} \mathrm{l}^{-1}$ ).

\section{Point B site}

In winter the water column was well mixed and the temperature was $13^{\circ} \mathrm{C}$ (Fig. 2b). From May to September 1999, the water column was stratified, with the thermocline well established at ca. $30 \mathrm{~m}$ depth (Fig. 2b). An increase in nitrate concentration occurred in March, earlier than in oceanic areas, with a maximum of $2 \mu \mathrm{mol} \mathrm{l}^{-1}$, and was followed by a

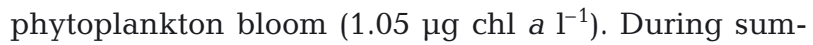

mer, the nitrate concentration was below $0.4 \mu \mathrm{mol} \mathrm{l}^{-1}$ (Fig. 2c). Phosphate concentrations reached maximum values of $0.12 \mu \mathrm{mol} \mathrm{l^{-1 }}$ in April, July and December; the rest of the year the concentration was below $0.09 \mu \mathrm{mol} \mathrm{l^{-1 }}$.

\section{Seasonal distribution of TEP: abundance and volume}

From February to May, the TEP abundance at DYFAMED and Point B remained low (under $0.35 \times 10^{5}$ TEP $\mathrm{ml}^{-1}$, Fig. 3). At DYFAMED, the TEP abundance increased strongly in June, reaching a maximum value of $2.2 \times 10^{5} \mathrm{TEP} \mathrm{ml} \mathrm{m}^{-1}$, and remained high until the autumn.

At Point B, the TEP concentration was high from June to September, attaining a maximum value of $0.55 \times 10^{5} \mathrm{TEP} \mathrm{ml}^{-1}$ in July. At both sites, TEP abundance decreased in autumn to the same values observed the previous winter.

The annual distribution of TEP concentration by size class is shown in Figs. 4 \& 5. At DYFAMED, TEP volume concentrations were low during winter and increased in April to reach a peak in June (Fig. 4a). After a decrease in July, the TEP volume concentration showed a second peak in August. In summer, most of the total TEP volume was made up of particles ranging from 4 to $12 \mu \mathrm{m}$ in diameter (more than $74 \%$ ). In autumn, the TEP concentration decreased for all size classes to reach the same values as before the spring bloom. At Point B, TEP volumes were lower than at DYFAMED (Fig. 4b). A peak was observed in March; from March to September the TEP volume was made up mostly of particles ranging from 5 to $17 \mu \mathrm{m}$ in diameter $(>50 \%)$.

TEP volume concentrations pooled for hydrological seasons are shown in Fig. 5. Maximum TEP volume occurred during summer and early autumn at DYFAMED,

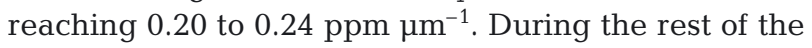

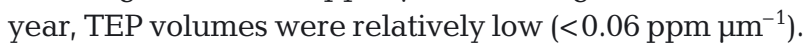
At Point B, TEP volume concentrations were highest in

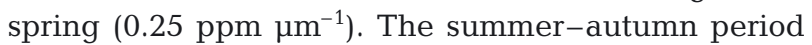
showed intermediary values, with volume concentra-

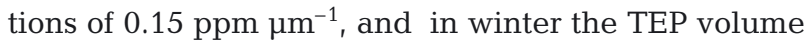
was low, with the same value as at DYFAMED during the same period. We observed a larger size range at Point B (ESD up to $135 \mu \mathrm{m}$ ) compared to DYFAMED, where the TEP size didn't exceed $100 \mu \mathrm{m}$.

\section{TEP size spectra}

The size spectra at both sites (Fig. 6) were similar, and followed a power-law distribution. However, the 
a)

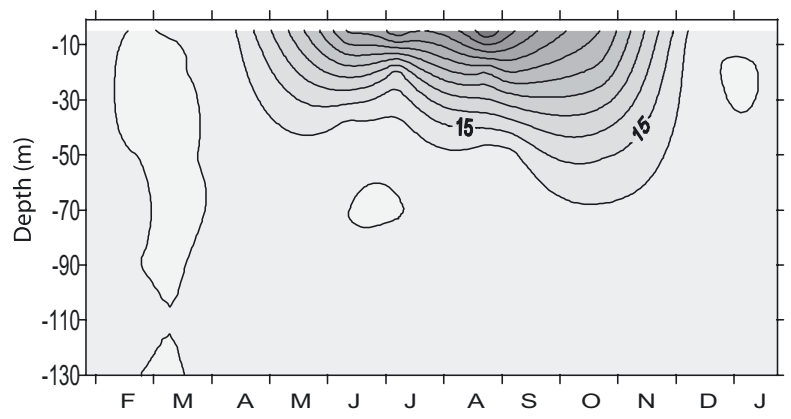

c)

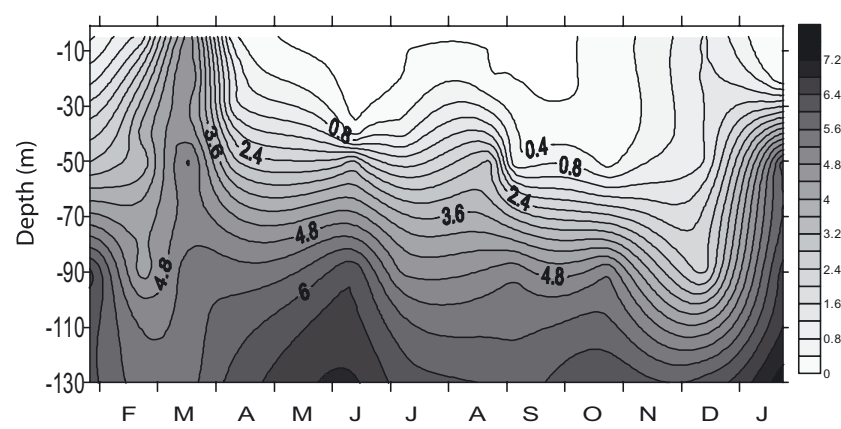

e)

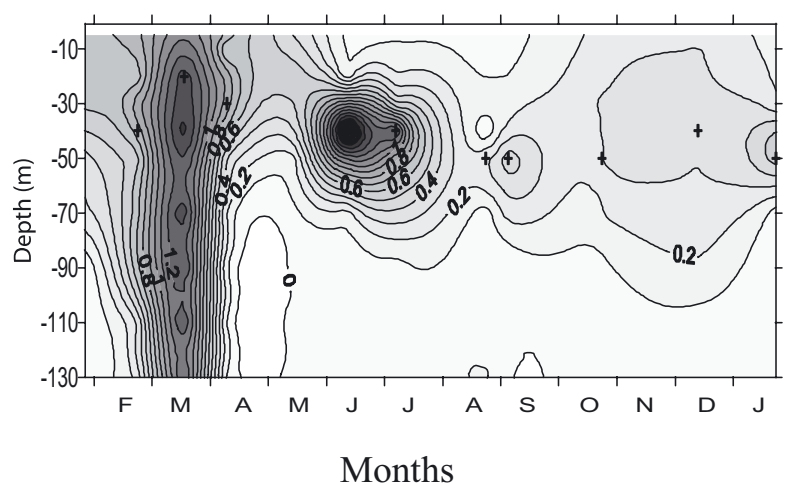

Point B

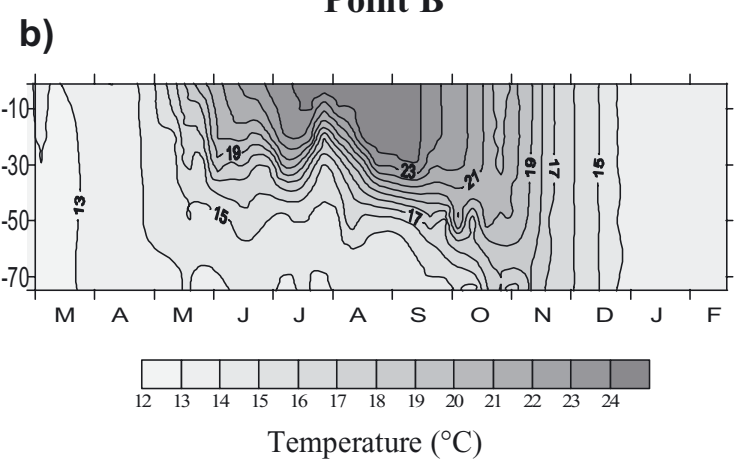

d)

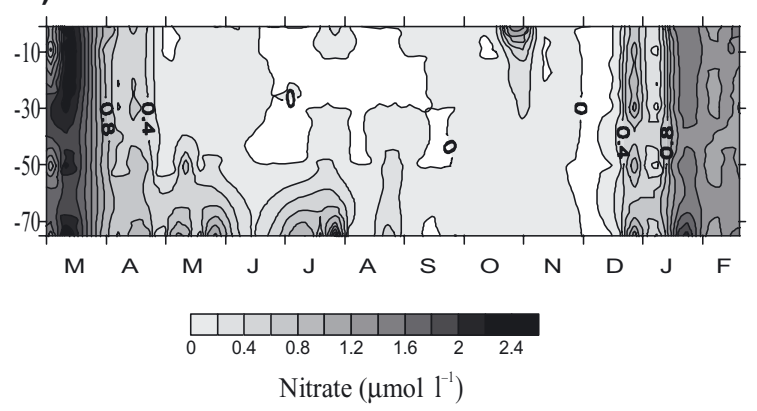

f)

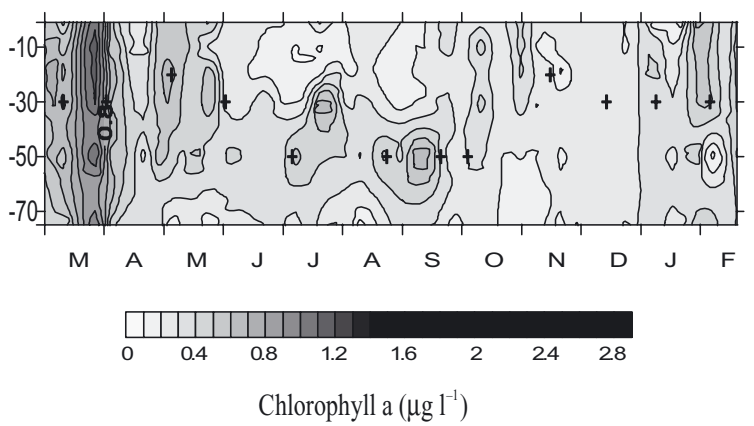

Months

Fig. 2. Seasonal water column variations of temperature $(\mathrm{a}, \mathrm{b})$, nitrate $(\mathrm{c}, \mathrm{d})$ and $\mathrm{chl}$ a concentrations (e,f) (crosses show transparent exopolymeric particle sampling depths). Data come from DYFAMED-JGOFS-France and INSU-SOMLIT programs (1999/2000). Note: scales are different for nitrate concentration

smallest size classes $(<1.5 \mu \mathrm{m})$ appeared to be underestimated. This deviation is probably due to sampling artifact. Indeed, even if the TEP count method used in this study is the best available, the filtration method may miss small particles which pass through filter pores due to the flexible character of TEP (Alldredge et al. 1993).

We tested for a season- or site-effect on the size distribution of TEP. Results of ANCOVA for the size spec- tra between DYFAMED and Point B sites did not significantly differ $(\mathrm{p}>0.5 ; \mathrm{df}=1,134)$. As size distribution of TEP was not influenced by the location, data were pooled together for further testing. Results showed that seasonal differences were highly significant ( $p<0.005$, df $=2,125$; Fig. 7). Slopes of regression lines were $-2.13 \pm 0.12$ for the spring, $-2.85 \pm 0.11$ for the stratified period, and $-3.20 \pm 0.14$ for the winter period. 


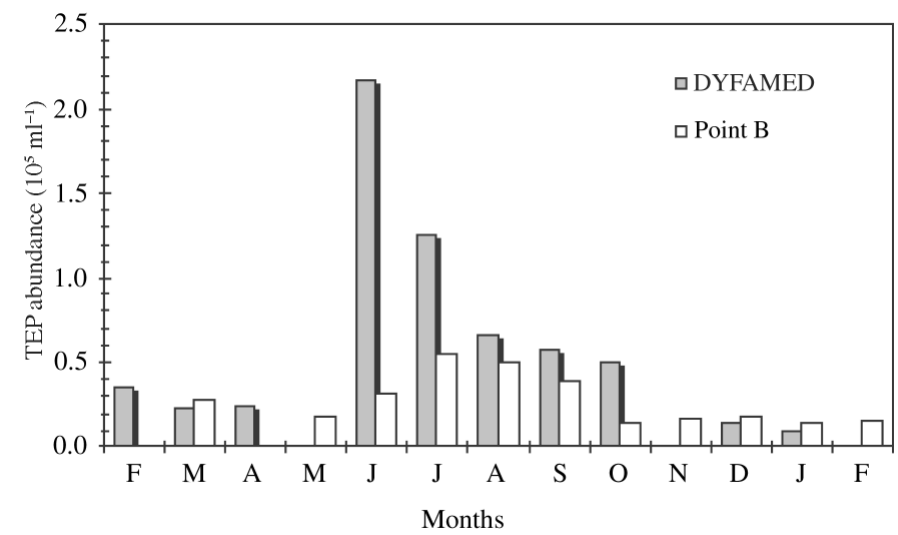

Fig. 3. Variation in transparent exopolymeric particle (TEP) abundance $\left(\times 10^{5} \mathrm{ml}^{-1}\right)$, from February 1999 to February 2000, in the NW Mediterranean Sea at DYFAMED and Point B. Missing data correspond to a missed cruise due to bad weather conditions

\section{TEP contribution to organic carbon pool}

The molar C:N ratio of TEP varied with time at Point B from $5.6 \pm 0.2$ to $80.5 \pm$ 7.2. The TEP C:N ratio increased from June to reach a maximum peak in July, and remained high in August (Fig. 8). The C:N ratio of TEP at DYFAMED followed the same pattern as that at Point B, with higher ratios during summer (73 in July). The C:N ratio of particulate organic matter (POM) at DYFAMED in the DCM layer varied from 6.2 to 14.3 . The C:N ratio of TEP was higher than the C:N ratio of POM, and higher than the Redfield ratio over almost the entire year.

The carbon contained in TEP (TEP-C) at Point $B$ ranged from $1.99 \mu \mathrm{mol} \mathrm{C} \mathrm{l}^{-1}$ in February to a maximum of $13.09 \mu \mathrm{molC} \mathrm{l}^{-1}$ in March, which coincided with the phytoplankton bloom (Table 1), while in DYFAMED a higher carbon content of TEP was found in summer. POM at DYFAMED at the DCM layer ranged

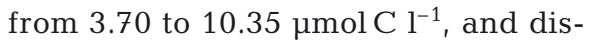
solved organic matter (DOC) ranged from 70 to $84 \mu \mathrm{mol} \mathrm{C} \mathrm{l}{ }^{-1}$. We attempted to estimate the TEP-C in relation to other organic pool in the NWM Sea. We summed the values of POC and DOC at DYFAMED for each TEP sampling period to generate a value for total organic carbon (TOC). At Point
$\mathrm{B}$, the TEP-C pool represented from 2 to $15 \%$ of the TOC. The TEP-C pool at DYFAMED represented up to $22 \%$ of the TOC during the summer period, and fell to $1 \%$ when TEP formation was low.

The relationship between POC and chl $a$ at DYFAMED was described by a linear regression $(y=$ $44.7 x+36.2$ ) estimated from plots of data from 1999 at the depth of maximum chl a. The slope of the regression line gives a C:chl a ratio of $45\left(\mathrm{R}^{2}=0.7 ; \mathrm{df}=7 ; \mathrm{p}<\right.$ 0.05 ; data not shown). Based on our calculations and conversion factors, the TEP-C concentration exceeded the algal POC concentration almost throughout the year at both sites.

From February to April 1999, during the nutrient-

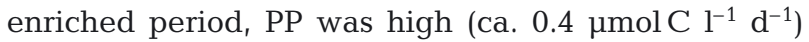
and the TEP-C concentration was low (Fig. 9). In June, after the phytoplankton bloom, the PP decreased

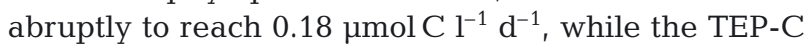
concentration increased until its maximum (20.51 $\mu \mathrm{molC} \mathrm{l}^{-1}$ ) and remained high during the nutrientdepleted period. From October, with the reinjection of nutrients to the surface, PP increased and TEP-C decreased.
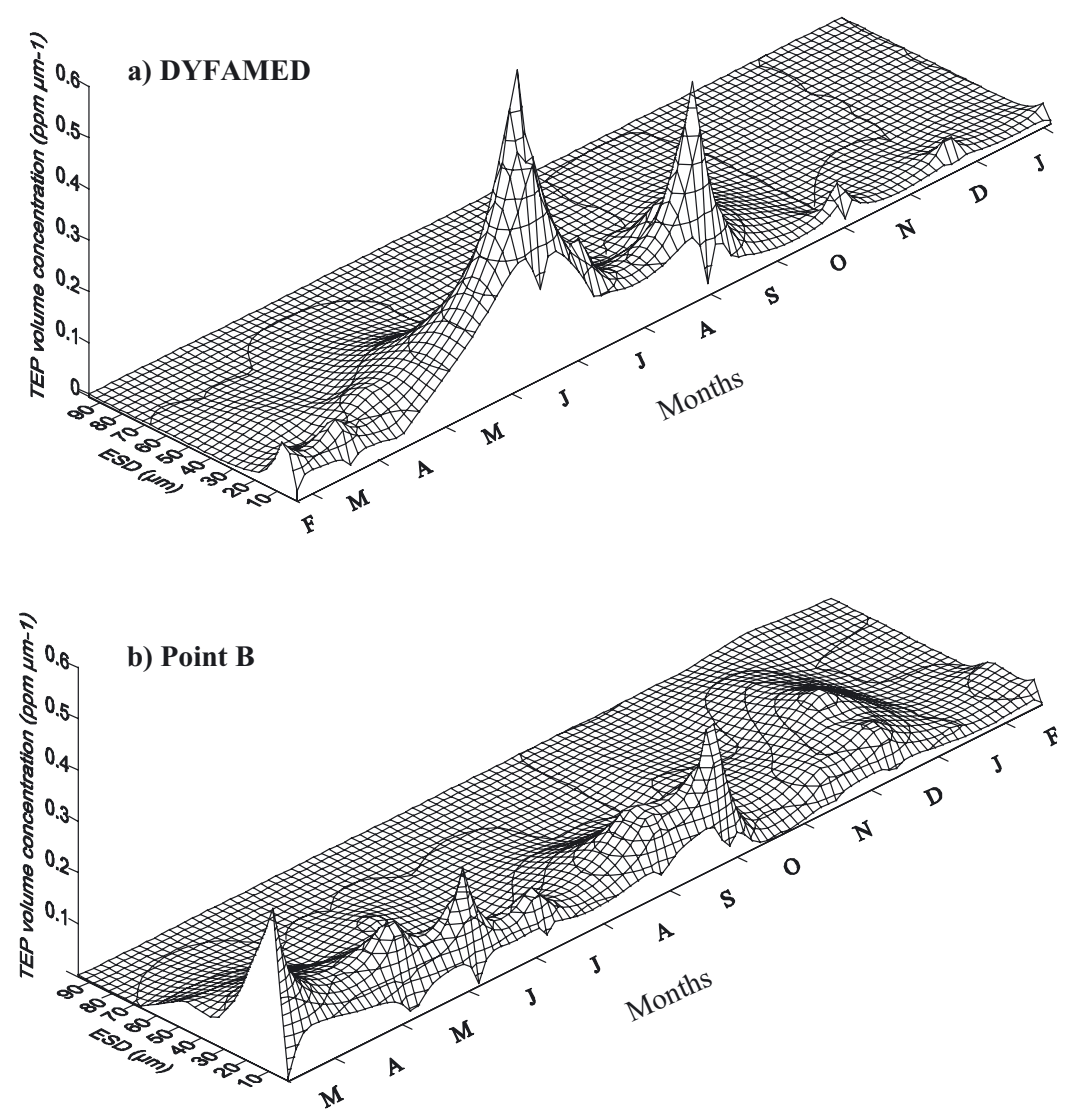

Fig. 4. Three-dimensional representation of transparent exopolymeric particle (TEP) volume concentration per size-class ESD (equivalent spherical diameter) at DYFAMED (a) and Point B (b), from February 1999 to January 2000 

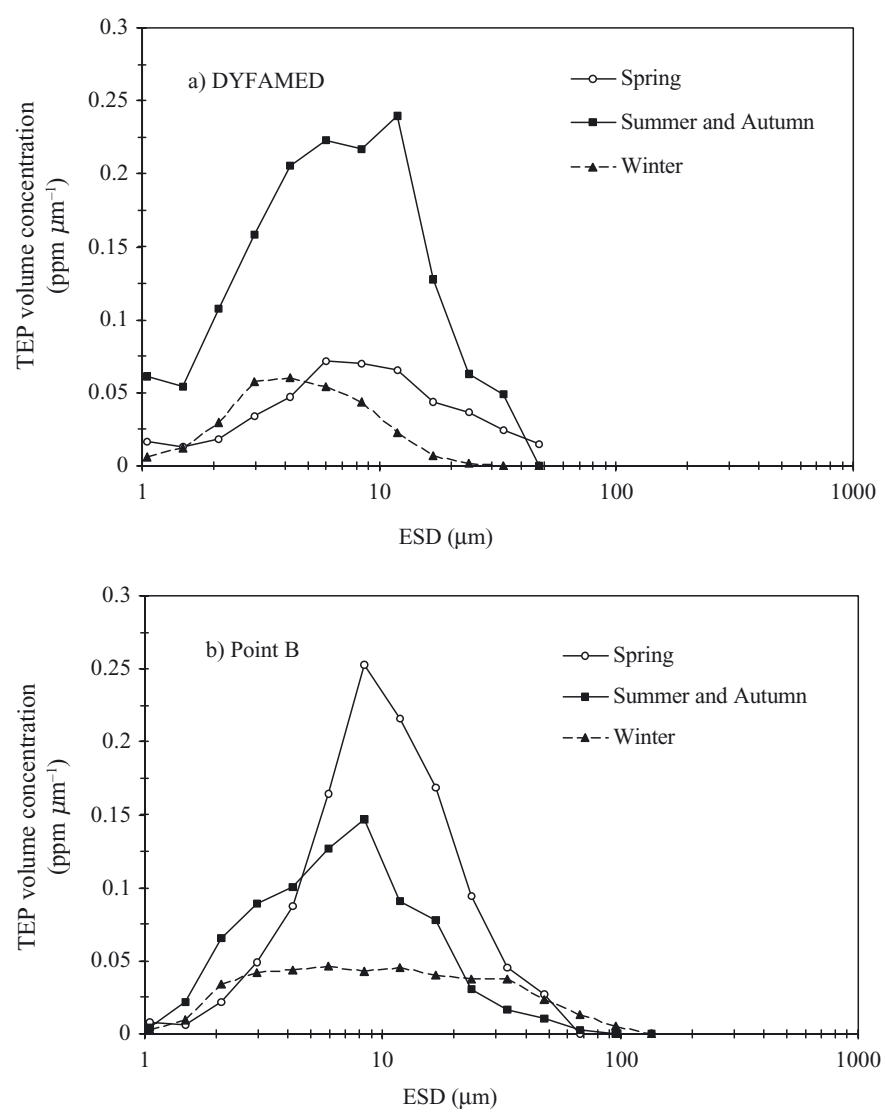

Fig. 5. Seasonal mean distribution of transparent exopolymeric particle (TEP) volume concentration at DYFAMED (a) and Point B (b), from February 1999 to January 2000. Summer and autumn were pooled as a stratified period. The equivalent spherical diameter (ESD) is presented in log scale

\section{DISCUSSION}

\section{Abundance of TEP and seasonal patterns}

In our study, TEP were found in relatively high abundances $\left(2 \times 10^{4}\right.$ to $\left.2.2 \times 10^{5} \mathrm{TEP} \mathrm{ml}^{-1}\right)$ at every sampling occasion, both at coastal and offshore sites. We found TEP concentrations to be 1 to 3 orders of magnitude higher than those reported for a variety of systems. For example, in the northern Adriatic Sea, Schuster \& Herndl (1995) found from 600 to $10^{3} \mathrm{TEP} \mathrm{ml}^{-1}$ in oligotrophic and mesotrophic stations, respectively. Passow \& Alldredge (1994) found from 4 to $5 \times 10^{3} \mathrm{TEP} \mathrm{ml}^{-1}$ in the surface waters of 2 coastal stations of California, and less than $10 \mathrm{TEP} \mathrm{ml}^{-1}$ in a deep oceanic site off Bermuda. Our high values likely reflect the methodology used. We observed TEP at 3 successive magnifications, and counts were made by employing image analyses software, allowing semi-automated counts (Mari \& Burd 1998). We also used a direct filtration with Cyto-Clear slides, so small TEP were observed more accurately. Such tech- niques permit quantification of TEP smaller than $3 \mu \mathrm{m}$. Our TEP concentration values were comparable to those found in the Kategatt (up to $3.8 \times 10^{5} \mathrm{TEP} \mathrm{ml}^{-1}$, Mari \& Burd 1998), and in a subarctic ria of Japan (up to $3.4 \times 10^{5}$ $\mathrm{ml}^{-1}$, Ramaiah et al. 2001). Interestingly, those sites were highly eutrophic $\left(12 \mu \mathrm{gchl}\right.$ a $\mathrm{l}^{-1}$ during the spring bloom), while the NWM Sea is an oligo-mesotrophic sea. As TEP are mainly formed by phytoplankton exudates (Alldredge et al. 1993), it is likely that TEP formation is rather linked to the phytoplankton activity than to the standing stock of phytoplankton (Schuster \& Herndl 1995).

In our study, TEP were more abundant at the offshore site, where chl a content was higher, compared to the coastal site. At DYFAMED, total TEP abundance was correlated with the $\mathrm{DCM}$ chl a concentration $(\mathrm{R}=0.71$; $\mathrm{p}<$ 0.05 ; df $=9$ ). But focusing on each TEP size-class, we observed that only the smaller TEP class $(\leq 2 \mu \mathrm{m})$ showed a positive correlation with chl a $(\mathrm{R}=0.82, \mathrm{p}<0.01, \mathrm{df}=9)$. In June, during the phytoplankton bloom, $46 \%$ of TEP belong to the small size classes $(<1.25 \mu \mathrm{m})$, while in August $65 \%$ of TEP were larger TEP (2.5 to $10 \mu \mathrm{m})$. We can hypothesize that small TEP were probably newly formed, and consequently they were nearer (in terms of space and time) to their phytoplanktonic source. While there is a general decrease in abundance (number of TEP $\mathrm{ml}^{-1}$ ) from spring to summer, the volume of TEP increases after the spring bloom and remains relatively high throughout the summer. This could be explained by the pattern of TEP size-frequency from small toward larger particles, suggesting that aggregation processes occur during summer. At the coastal station, there was no correlation between TEP and chl a. At this site, high TEP volume was observed in spring following the March bloom, suggesting aggregation by coagulation between TEP and algal cells. The hydrology of the coastal area (Point B) is more complex since it is influenced by coastal winds and the Ligurian Current, while the DYFAMED site is regarded as a $1 \mathrm{D}$ station, where horizontal advection is minor.

TEP size spectra showed a power-law function from each sampling, and were consistent with the coagulation model (power-law function, slopes of ca. 3, McCave 1984). They are thought to be primarily formed by coagulation of colloidal precursors (Mari \& Burd 1998). Over the whole the year, pooling both sites, slopes of pooled data were 2.13 (spring), 2.85 (stratified period) and 3.20 (winter). The regression slope was the highest in the winter period, meaning that smaller particles were relatively more abundant than larger ones compared to spring and summer periods. Deviations from the theoretical slope $(\delta=3$ ) could be explained by biological and physical processes. The strong water mixing during winter could desegregate TEP into smaller particles. Indeed, according to Passow \& Alldredge (1994), fragmentation or desegregation processes lead to a steeper slope. 
DYFAMED
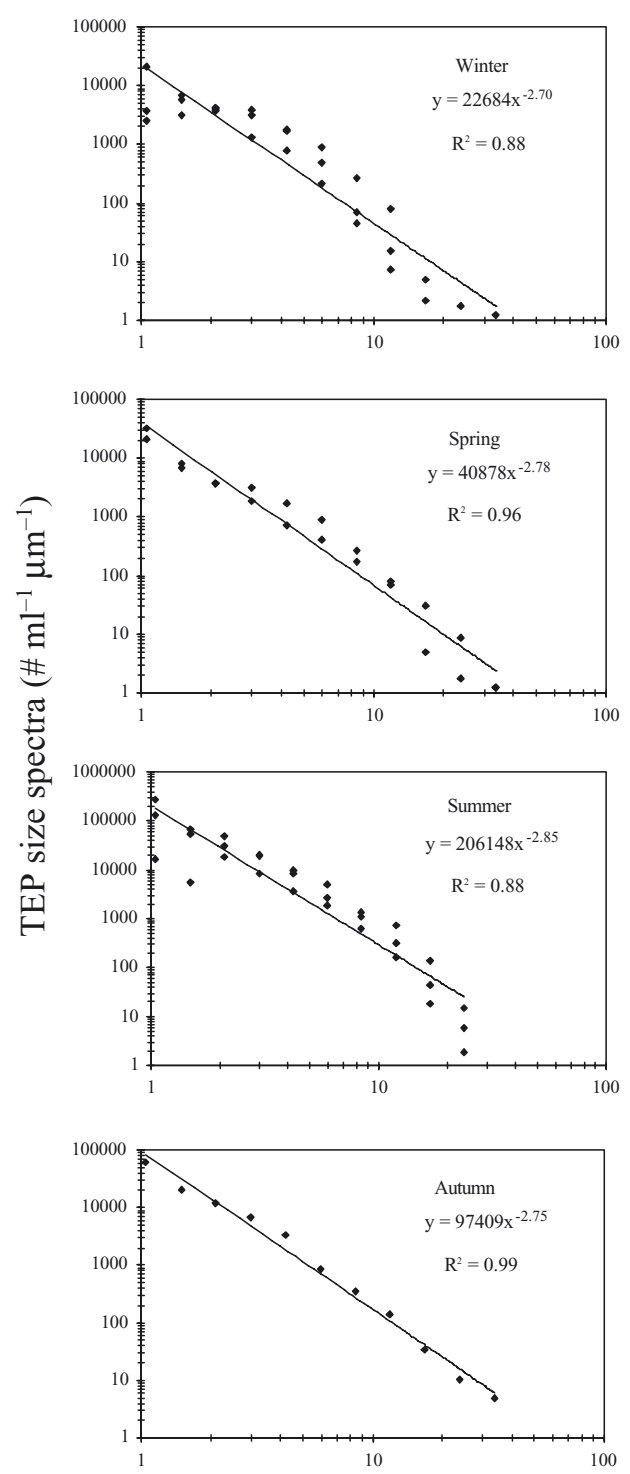

Point B
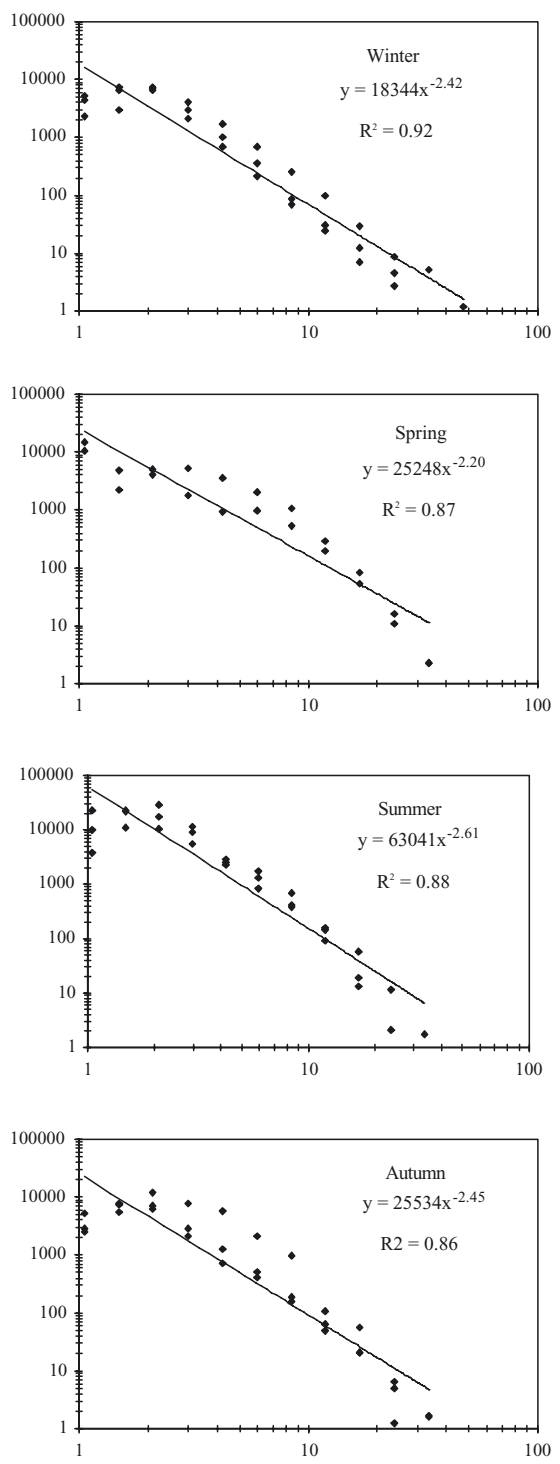

Equivalent spherical diameter, $d_{\mathrm{p}}(\mu \mathrm{m})$

Fig. 6. Transparent exopolymeric particle (TEP) size spectra with log-log transformation, at DYFAMED and Point B. Regression lines $\left(\mathrm{d} N / \mathrm{d}\left[d_{\mathrm{p}}\right]=\mathrm{k} d_{\mathrm{p}}{ }^{\delta}\right)$ have been fitted to the data. Graphs show all monthly data averaged by season (see 'Size distribution and TEP volume' for equation details)

\section{TEP contribution to the carbon cycle}

Based on the stoichiometric model of Redfield (1963), Sambrotto et al. (1993) distinguished conditions of elevated carbon consumption relative to nitrogen that exceeded the Redfield $\mathrm{C}: \mathrm{N}$ ratio. Using the $\mathrm{C}: \mathrm{N}$ ratio to convert new production to carbon can underestimate net organic carbon production by more than $50 \%$. This 'spring-summer imbalance of dissolved inorganic carbon' has been reported for different marine systems
(Banse 1994, Marchal et al. 1996, Copin-Montégut 2000, Körtzinger et al. 2001). The explanation for such an apparent carbon overconsumption by phytoplankton was held in the formation of a large standing stock of organic matter, with an abnormal C:N ratio, that accumulated in the euphotic zone from spring bloom to late summer (Copin-Montégut \& Avril 1993, Toggweiler 1993, Carlson et al. 1994, Williams 1995).

Mari et al. (2001), using a subset of the data analyzed here, showed that the measured C:N ratios of TEP at the DYFAMED station during N-limiting conditions (in 1999) are consistent with the net DIC: $\mathrm{NO}_{3}$ assimilation ratios reported for the same area by CopinMontégut (2000). Our results at the coastal site confirmed this general pattern, with an increase in the TEP C:N ratio from June to reach a maximum value in summer (80), with an average $\mathrm{C}: \mathrm{N}$ molar ratio of 22. Based on those results, the $\mathrm{C}: \mathrm{N}$ ratio of the $\mathrm{POM}$ is not an accurate index of the total organic matter produced, and thus cannot be used to link the production of new organic matter to the amount of atmospheric $\mathrm{CO}_{2}$ transferred to the ocean's surface.

Our results showed that at the DYFAMED and Point B sites, during the oligotrophic period, the increase in TEP abundance is relatable to nitrate limitation and a decline in primary production. Experimental evidence supports the idea that $\mathrm{N}$ or $\mathrm{P}$ limitation influence phytoplankton extracellular release (Myklestad 1977, Obernosterer \& Herndl 1995, Penna et al. 1999). With regard to TEP directly, a link between TEP production and N-limitation was shown in vitro by Corzo et al. (2000), using diatom cultures. In mesocosm experiments, Engel et al. (2002) documented a decoupling of carbon from nitrogen and phosphorus after nitrate depletion, with a resultant large flow of carbon into the TEP pool and an elevation of the POC:PON ratio. In field studies, Mari \& Burd (1998) found evidence for increased TEP abundance when nutrients were low in the surface mixed layer in the Kattegat.

However, our study is the first to assess in-the-field links between TEP and primary production. Our data 


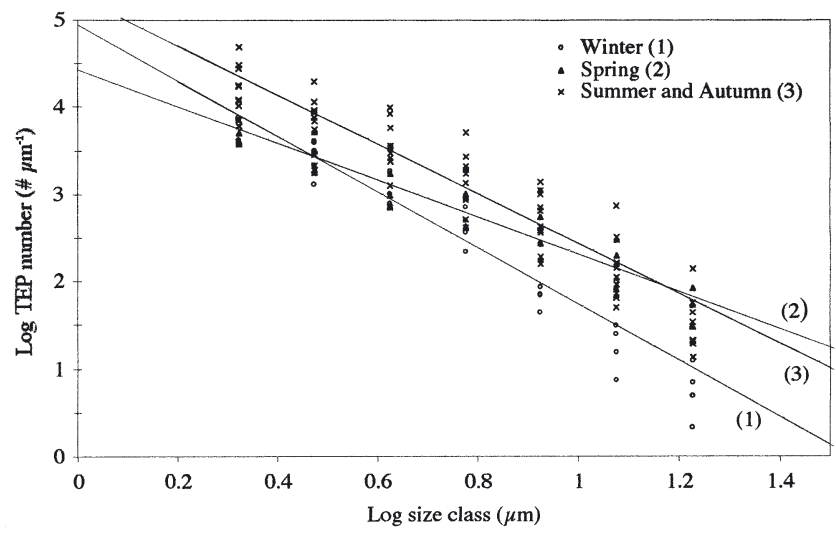

Fig. 7. Results of transparent exopolymeric particle (TEP) size spectra ANCOVA. DYFAMED and Point B data were pooled together for different seasons ( $p=0.19 ; n=137)$. (1), (2) and (3) regression lines correspond to the winter, spring and summer-autumn (= stratified) periods, respectively

suggest that the relationships are not simply linear. Results shown in Fig. 9 suggest a temporal uncoupling between TEP-C concentration and primary production. In 1999, the seasonal variation of primary production showed a large range of values throughout the year, with maximum values in March and April and lower values in summer and fall, during the period where TEPs were most abundant. During summer, the low nitrate concentrations limit the phytoplanktonic biomass production, but net carbon uptake continues

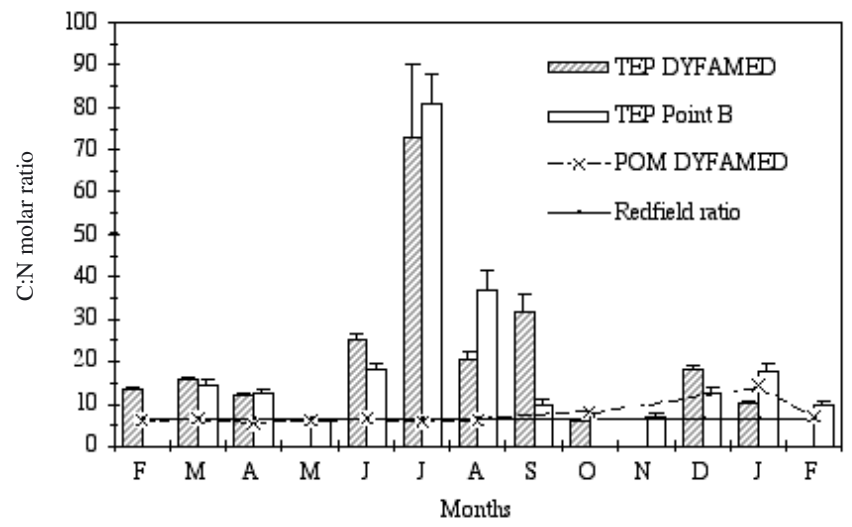

Fig. 8. Molar C:N ratio of transparent exopolymeric particles (TEP) from March 1999 to February 2000 at Point B and DYFAMED (from Mari et al. 2001). The molar C:N ratio of particulate organic matter (POM) at DYFAMED and the Redfield ratio are also represented

and is channelled into the production of transparent exopolymer products.

This study suggests that TEP may represent a significant carbon fraction, at the coastal site and offshore, at least during non-bloom conditions. The accumulation of TEP observed at the DYFAMED station from midJune to mid-September represented up to $22 \%$ of the total organic carbon (TOC). The TEP-C concentration in summer is high compared to other sources of POM. At DYFAMED it correspond to $183 \%$ of the total stand-

Table 1. Particulate organic carbon (POC), dissolved organic carbon (DOC), organic carbon due to phytoplankton (C-Phyto) and carbon contained in TEP (TEP-C) at the DYFAMED and Point B sites, from February 1999 to February 2000. The fraction of TEP$\mathrm{C}$ was compared to total organic carbon (TOC). TOC was calculated from the sum of POC and DOC. Organic carbon due to phytoplankton was calculated using a C:chl a ratio of 45, with chl a data from JGOFS and SOMLIT databases (1999 to 2000). All data were from the depth of the chlorophyll maximum (DCM) in order to allow comparisons

\begin{tabular}{|c|c|c|c|c|c|c|c|c|}
\hline & $\begin{array}{c}\text { POC } \\
\left(\mu \mathrm{mol} \mathrm{C} 1^{-1}\right)\end{array}$ & $\begin{array}{c}\text { DOC } \\
\left(\mu \mathrm{mol} \mathrm{C} 1^{-1}\right)\end{array}$ & 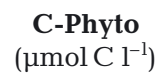 & 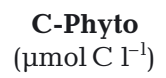 & $\begin{array}{c}\text { TEP-C } \\
\left(\mu \mathrm{mol} \mathrm{C} \mathrm{l}^{-1}\right)\end{array}$ & $\begin{array}{c}\text { TEP-C } \\
\left(\mu \mathrm{mol} \mathrm{C} 1^{-1}\right)\end{array}$ & - TEP-C: & OC \\
\hline Location: & DYFAMED & DYFAMED & DYFAMED & Point B & DYFAMED & Point B & DYFAMED & Point B \\
\hline Source: & $\begin{array}{l}\text { JGOFS } \\
\text { Data base }\end{array}$ & $\begin{array}{l}\text { Avril } \\
(2002)\end{array}$ & $\begin{array}{l}\text { Present } \\
\text { study }\end{array}$ & $\begin{array}{l}\text { Present } \\
\text { study }\end{array}$ & $\begin{array}{l}\text { Mari et al. } \\
\text { (2001) }\end{array}$ & $\begin{array}{l}\text { Present } \\
\text { study }\end{array}$ & $\begin{array}{l}\text { Present } \\
\text { study }\end{array}$ & $\begin{array}{l}\text { Present } \\
\text { study }\end{array}$ \\
\hline \multicolumn{9}{|l|}{ Month } \\
\hline Feb & 3.70 & 77.5 & 3.24 & & 2.96 & & 4 & \\
\hline Mar & 7.5 & 78.5 & 5.42 & 1.94 & 3.56 & 13.09 & 4 & 15 \\
\hline Apr & 7.4 & 84 & 3.23 & 2.20 & 3.90 & & 4 & \\
\hline May & 4.8 & 83 & 2.15 & 2.40 & & 7.22 & & 8 \\
\hline Jun & 10.35 & 81 & 7.24 & 0.82 & 20.51 & 6.58 & 22 & 7 \\
\hline Jul & 7.39 & 81.5 & 5.08 & 2.17 & 8.55 & 4.29 & 10 & 5 \\
\hline Aug & 4.94 & 75 & 1.05 & 2.13 & 11.56 & 7.63 & 14 & 10 \\
\hline Sep & & 70 & 1.77 & 1.30 & 7.45 & 8.23 & & \\
\hline Oct & 5.95 & 70 & 1.31 & 0.98 & 1.94 & 3.68 & 3 & 5 \\
\hline Nov & & 82 & & 0.72 & & 3.99 & & \\
\hline Dec & & 82 & 1.23 & 1.06 & 1.37 & 8.21 & & \\
\hline Jan & 6.35 & 77.5 & 2.09 & 1.40 & 0.64 & 2.04 & 1 & 2 \\
\hline Feb & 7.13 & 78.5 & & 2.03 & & 1.99 & & 2 \\
\hline
\end{tabular}




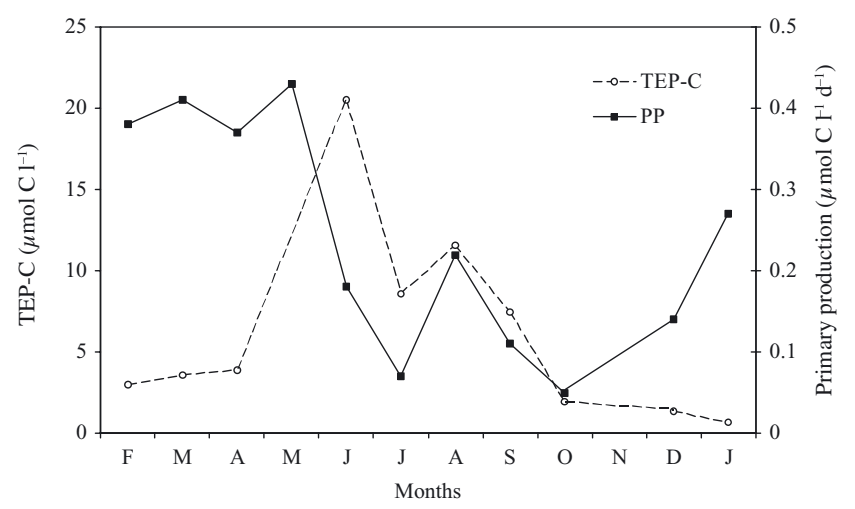

Fig. 9. Transparent exopolymeric-particle carbon (TEP-C) concentration and primary production at DYFAMED, from February 1999 to January 2000. Primary production data come from the depth of the chlorophyll maximum (DCM) layer as TEP measurements (DYFAMED-JGOFS-France)

ing stock of POC (considering an average summer TEP-C concentration of $13 \pm 6 \mu \mathrm{M}$ ). Since it is most unlikely that the TEP carbon concentration exceeds POC, it appears that either the TEP carbon content calculated from TEP produced in the laboratory overestimates the carbon content of naturally occurring TEP, or POC was underestimated. According to Engel \& Passow (2001) the relationship between carbon and TEP is species-specific. Our estimates of carbon concentration of TEP derived from the theoretical size-relationships found by Mari (1999) were the result of TEP produced in the laboratory by coagulation of diatom exudates. It is likely that this relationship is not adequate to estimate TEP-C content during summer in the NWM Sea, where groups other than diatoms represent a major part of the phytoplankton community (Marty et al. 2002).

Engel \& Passow (2001) calculated the TEP-C concentration for various marine sites; for the northern Adriatic Sea, they reported TEP-C values to represent $103 \%$ of measured POC. This authors suggested that some fraction of TEP is measured as DOC, because TEP cannot be retained quantitatively in GF/F filters. During summer at DYFAMED, the increase in TEP concentration is consistent with the accumulation of carbon-rich DOM (Avril 2001), some of which coagulates into TEP. TEP-C concentration corresponded to $25 \%$ of the DOC; therefore, we can hypothesize that some varying fraction of TEP-C is also measured as DOC, which suggests that other processes could be involved in TEP dynamics. TEP are arbitrarily defined as particulate matter since they are observed after filtration on $0.2 \mu \mathrm{m}$ pore-sized filters. As they are formed abiotically by coagulation of high molecular weight DOM as colloids (Johnson et al. 1986, Chin et al. 1998,
Passow 2000), TEP-C should not be partitioned between DOC and POC according to the traditional way of measuring those stocks. Colloids are highly abundant in seawater $\left(>10^{7} \mathrm{ml}^{-1}\right)$ and their formation is very dynamic, with high aggregation rates (Wells 1998). The polymer gelation theory suggests that there is a dynamic steady state between colloids and particle fractions, and that assembly kinetics is concentrationdependent (Chin et al. 1998). TEP may represent an important intermediary pool of organic matter in the ocean. The production of TEP could be an important pathway for the carbon overconsumption required in oligotrophic, nitrate-limiting waters and for the sequestration of dissolved organic carbon. This study constitutes a first attempt to estimate the significance of the TEP pool in relation to other organic pools in the field; new techniques will be necessary to better define this significance.

\section{TEP dynamics in the NWM Sea}

In the NWM Sea, the year can be separated into 2 distinct hydrological seasons: a mesotrophic period where strong winter vertical mixing brings nutrients from deep waters, allowing a winter-spring bloom in the surface (Minas et al. 1988); and an oligotrophic period, from spring to late summer, where the water column becomes stratified and depleted in nutrients (Béthoux et al. 1988).

The trophic status of the western Mediterranean Sea can also be assessed using the Fp-ratio. This ratio, described by Claustre (1994) as the ratio of large phytoplankter pigment biomass to the total pigment biomass, estimates the importance of new vs regenerated production and the linked phytoplankton community. In 1999, the mesotrophic regime corresponded to a high $(80 \%)$ Fp ratio at DYFAMED, which was associated with a large diatom bloom in March (the fucoxanthine concentration reached $100 \mathrm{mg} \mathrm{m}^{-2}$ when the average values for this area was $7.1 \mathrm{mg} \mathrm{m}^{-2}$, Marty et al. 2002), and maximum values of DOC were observed (Avril 2002). High concentrations of TEP are often linked to diatom blooms (Passow \& Alldredge 1994, Mari \& Burd 1998, Passow et al. 2001); however, we observed low TEP concentrations shortly after the bloom, both in coastal and offshore stations. It is possible that TEP formed after the bloom coagulated with diatoms and rapidly sedimented. The high stickiness coefficient of TEP may facilitate the formation and sedimentation of fast-sinking aggregates during phytoplankton blooms (Passow \& Alldredge 1994, Logan et al. 1995), and the strong particulate flux observed during this period by Miquel \& La Rosa (1999) at DYFAMED are linked to this sinking. 
Oligotrophic conditions began at the end of spring, when the water column became stratified and the thermocline, at about $40 \mathrm{~m}$ depth in June, isolated superficial water from the rest of the water column, thus limiting vertical exchanges. During the stratified period, the Fp-ratio decreased to an average of $15 \%$ and the late-spring bloom was dominated by nanoflagellates (Marty et al. 2002). The high TEP abundance observed in June at DYFAMED was linked to newly formed TEP during the bloom, and could be explained by phytoplankton activity (i.e. exudation of DOM from cells and subsequent coagulation). However, the build-up of a large pool of TEP in August was apparently not related to the nanoflagellate bloom; nevertheless, it coincided with the DOC accumulation observed in this region in summer (Copin-Montégut \& Avril 1993, Avril 2002). From the spring bloom and during the summer season, phytoplankton and bacteria produce large amounts of C-rich DOM that is continuously accumulated in the surface layer, with a maximum of $82 \mu \mathrm{MC}$ at $34 \mathrm{~m}$ depth in August and $90 \mu \mathrm{MC}$ in September (Avril 2002). As the pool of TEP exhibits a seasonal pattern similar to that of dissolved organic matter, Mari et al. (2001) suggested that this C-rich pool is the origin of TEP.

The remaining questions are: Why is there a summer accumulation of TEP, and what are the consequences of this accumulation? The summer period is characterized by nutrient-depleted conditions in the surface layer that favour exopolymer production by phytoplankton (Obernosterer \& Herndl 1995). The transition to oligotrophic conditions corresponds to an increase in the relative contribution of flagellates and picoplankters (cyanobacteria and prochlorophytes) to the phytoplankton community, which exhibits low export rates (Marty et al. 2002). We hypothesize that TEP accumulation in the oligotrophic zone throughout summer is controlled by aggregation processes, which occur through higher production of photosynthetic extracellular products by small picoplankters, thus supporting regenerated production. During this period, the increase in the carbon assimilation rate is linked to the period of phosphorus limitation and abundance of cyanobacteria (Marty \& Chiaverini 2002), and TEP remain in the water column because of strong thermal stratification and lower summer turbulence, and the pycnocline represents a true barrier against sinking.

Stratification of a system changes the particle dynamics, increasing the number of larger particles and speeding up the onset of coagulation (Jackson 1990). Like the surface DOC-pool, the TEP-pool is considered labile and freshly produced. Thus the residence time of the TEP-pool in the water column will also depend on degradation, or not, by bacteria. In addition to the $\mathrm{N}$-limited conditions which prevail in superficial waters during the spring and summer period, it has been shown that $\mathrm{P}$ is a limiting factor in the NWM Sea (Coste et al. 1988, Béthoux et al. 1998). This limitation is particularly important during the oligotrophic period, where the N:P ratio for superficial waters is always greater than 20 (Marty et al. 2002). Enrichment experiments in surface waters of the open NWM Sea (Sala et al. 2002, Van Wambeke et al. 2002) and at Point B (Zweifel et al. 1993, Thingstad et al. 1999, Hagström et al. 2001) showed that bacterial communities are P-limited during the stratified period. In batch cultures under P-limited conditions, the phytoplankton release dissolved monomeric and polymeric carbohydrates that are not consumed efficiently by heterotrophic bacteria (Obesrnosterer \& Hendl 1995). In the Mediterranean Sea, accumulation of degradable material in surface waters during summer can be explained by a malfunctioning of the microbial food web, with a restricted bacterial degradation of DOC due to a combination of P-limitation and predatory control (Thingstad \& Rassoulzadegan 1995, Thingstad et al. 1997). Under P-limited conditions, heterotrophic bacteria will not be able to solubilize TEP, nor will they be able to metabolize the resulting organic dissolved carbon. During the stratified period in 1999 (from 0.05 to $0.10 \mu \mathrm{mol} \mathrm{C}^{-1} \mathrm{~d}^{-1}$ ), the lower bacterial production at DYFAMED in the surface layer, compared to bloom periods in March and June (from 0.15 to $0.30 \mu \mathrm{molC} \mathrm{l}^{-1} \mathrm{~d}^{-1}$, Lemée et al. 2002), could explain such limitation.

Production of TEP and subsequent aggregation into larger particles could have some consequences for the flux of matter, but this depends on whether TEP settles faster than the rate of bacterial decomposition. From October, de-stratification leads to the mixing of superficial waters; during this period, Avril (2002) observed the transport of dissolved organic carbon by diffusion and downwelling. The low TEP abundance observed after summer could be attributed to those processes. Nevertheless, an increase in vertical flux due to TEP is not consistent with results of the vertical flux of particles observed at DYFAMED for this period. Indeed, Miquel \& La Rosa (1999) showed that mass and carbon fluxes at $200 \mathrm{~m}$ were highest during winter and spring, and minimal during summer and autumn. However, the carbon fraction of sinking particles was maximal during summer/autumn, with a relatively high C:N ratio. If one considers the $\mathrm{C}: \mathrm{N}$ ratio of POM collected at $200 \mathrm{~m}$ from sediment traps in October and November 1999 (10.7 and 7.6 respectively, J. C. Miquel pers. comm.), and assuming that non-TEP POM has a $\mathrm{C}: \mathrm{N}$ value close to the Redfield ratio, this extra carbon could be composed of TEP-like material, suggesting that TEP can act as important regulator of the $\mathrm{C}: \mathrm{N}$ ratio of total organic matter. 
Although TEP abundance followed distinctly different seasonal patterns at the coastal and offshore site, TEP formation and TEP-C content showed similar patterns at both sites of the NWM Sea. This leads us to conclude that TEP production is primarily governed by biological and chemical forcing. In the NWM Sea, the trophic status of the environment and the composition of primary producers control TEP formation and accumulation. Hydrological processes are also of primary importance, as they govern the seasonal TEP distribution.

Acknowledgements. We thank S. Dallot, J. Dolan and X. Mari for helpful comments, and DYFAMED observation service and INSU/CNRS SOMLIT for providing physical-chemical data. This work was supported by CNRS, INSU (ATI), the PROOF-DYFAMED programme (JGOFS, France) and EU Project NTAP (EVK3-CT-2000-00022) of the EU RTD Programme 'Environment and Sustainable Development'. It forms part of the ELOISE project cluster, and is Eloise Contribution No. 447/40.

\section{LITERATURE CITED}

Alldredge AL, Passow U, Logan BE (1993) The abundance and significance of a class of large, transparent organic particles in the ocean. Deep-Sea Res 40:1131-1140

Andersen V, Prieur L (2000) One-month study in the open NW Mediterranean Sea (DYNAPROC experiment, May 1995): overview of the hydrobiological structures and effects of winds events. Deep-Sea Res 47:397-422

Avril B (2002) DOC dynamics in the northwestern Mediterranean Sea (DYFAMED site). Deep-Sea Res 49:2163-2182

Banse K (1994) Uptake of inorganic carbon and nitrate by marine plankton and the Redfield ratio. Global Biogeochem Cycles 8:81-84

Béthoux JP, Prieur L (1983) Hydrologie et circulation en Méditerranée Nord-Occidentale. Pét Tech 299:25-34

Béthoux JP, Prieur L, Bong JH (1988) Le courant Ligure au large de Nice. Oceanol Acta 9:59-67

Béthoux JP, Morin P, Chaumery C, Connan O, Gentili B, RuizPino D (1998) Nutrients in the Mediterranean Sea, mass balance and statistical analysis of concentrations with respect to environmental changes. Mar Chem 63:155-169

Carlson CA, Ducklow HW, Michaels AF (1994) Annual flux of dissolved organic carbon from the euphotic zone in the northwestern Sargasso Sea. Nature 371:405-408

Chin WC, Orellana MV, Verdugo P (1998) Spontaneous assembly of marine dissolved organic matter into polymer gels. Nature 391:568-572

Claustre H (1994) The trophic status of various oceanic provinces as revealed by phytoplankton pigment signatures. Limnol Oceanogr 39:1206-1210

Copin-Montégut C (2000) Consumption and production on scales of a few days of inorganic carbon, nitrate and oxygen by the planktonic community: results of continuous measurements at the Dyfamed Station in the nortwestern Mediterranean Sea (May 1995). Deep-Sea Res 47:447-477

Copin-Montégut G, Avril B (1993) Vertical distribution and temporal variation of dissolved organic carbon in the north-western Mediterranean Sea. Deep-Sea Res 40: 1963-1972
Corzo A, Morillo JA, Rodriguez S (2000) Production of transparent exopolymeric particles (TEP) in cultures of Chaetoceros calcitrans under nitrogen limitation. Aquat Microb Ecol 23:63-72

Coste B, Le Corre P, Minas HJ (1988) Re-evaluation of the nutrient exchanges in the Strait of Gibraltar. Deep-Sea Res 35:767-775

Dandonneau Y, Le Bouteillier A (1992) A simple and rapid device for measuring planktonic primary production by in situ sampling, and ${ }^{14} \mathrm{C}$ injection and incubation. Deep-Sea Res 39:795-803

Engel A (2002) Direct relationship between $\mathrm{CO}_{2}$ uptake and transparent exopolymeric particles production in natural phytoplankton. J Plankton Res 24:49-53

Engel A, Passow U (2001) Carbon and nitrogen content of transparent exopolymeric particles (TEP) in relation to their Alcian Blue adsorption. Mar Ecol Prog Ser 219:1-10

Engel A, Goldthwait S, Passow U, Alldredge A (2002) Temporal decoupling of carbon and nitrogen dynamics in a mesocosm diatom bloom. Limnol Oceanogr 47:753-761

Fowler SW, Knauer GA (1986) Role of large particles in the transport of elements and organic compounds through the oceanic water column. Prog Oceanogr 16:147-194

Grossart H, Simon M, Logan BE (1997) Formation of macroscopic organic aggregates (lake snow) in a large lake: the significance of transparent exopolymer particles, phytoplankton, and zooplankton. Limnol Oceanogr 42: $1651-1659$

Grossart HP, Berman T, Simon M, Pohlman K (1998) Occurence and microbial dynamics of macroscopic organic aggregates (lake snow) in Lake Kinneret, Israel, in fall. Aquat Microb Ecol 14:59-67

Hagström Å, Pinhassi J, Zweifel UI (2001) Marine bacterioplankton show burst or rapid growth induced by substrate shifts. Aquat Microb Ecol 24:109-115

Hewes CD, Holm-Hansen O (1983) A method for recovering nanoplankton from filters for identification with the microscope: the filter-transfer-freeze (FTF) technique. Limnol Oceanogr 28 (2):389-394

Jackson GA (1990) A model of the formation of marine algal flocs by physical coagulation processes. Deep-Sea Res 37: $1197-1211$

Johnson BD, Zhou X, Wangersky PI (1986) Surface coagulation in sea water. Neth J Sea Res 20:201-210

Kiørboe T, Hansen LS (1993) Phytoplankton aggregate formation: observations of patterns and mechanisms of cell sticking and the significance of exopolymeric material. J Plankton Res 15:993-1018

Körtzinger A, Hedges JI, Quay PD (2001) Redfield ratios revisited: removing the biasing effect of anthropogenic $\mathrm{CO}_{2}$. Limnol Oceanogr 46:964-970

Lemée R, Rochelle-Newall E, Van Wambeke F, Pizay MD, Rinaldi P, Gattuso JP (2002) Seasonal variation of bacterial production, respiration and growth efficiency in the open NW Mediterranean Sea. Aquat Microb Ecol 29:227-237

Logan BE, Grossart HP, Simon M (1994) Direct observation of phytoplankton, TEP and aggregates on polycarbonate filters using brightfield microscopy. J Plankton Res 16: $1811-1815$

Logan BE, Passow U, Alldredge AL, Grossart HP, Simon M (1995) Rapid formation and sedimentation of large aggregates is predictable from coagulation rates (half-lives) of transparent exopolymer particles (TEP). Deep-Sea Res 42: 203-214

Marchal O, Monfray P, Bates NR (1996) Spring-summer imbalance of dissolved inorganic carbon in the mixed layer of the northwestern Sargasso Sea. Tellus 48:115-134 
Mari X (1999) Carbon content and C:N ratio of transparent exopolymeric particles (TEP) produced by bubbling exudates of diatoms. Mar Ecol Prog Ser 183:59-71

Mari X, Burd A (1998) Seasonal size spectra of transparent exopolymeric particles (TEP) in a coastal sea and comparison with those predicted using coagulation theory. Mar Ecol Prog Ser 163:63-76

Mari X, Kiørboe T (1996) Abundance, size distribution and bacterial colonization of transparent exoplymeric particles (TEP) during spring in the Kattegat. J Plankton Res 18:969-986

Mari X, Beauvais S, Lemée R, Pedrotti ML (2001) Non-Redfield C:N ratio of transparent exopolymeric particles in the northwestern Mediterranean Sea. Limnol Oceanogr 46: 1831-1836

Marty JC, Chiaverini J (2002) Seasonal and interannual variations in phytoplankton production at DYFAMED timeseries station, northwestern Mediterranean Sea. DeepSea Res 49:2017-2030

Marty JC, Chiaverini J, Pizay MD, Avril B (2002) Seasonal and interannual dynamics of nutrients and phytoplankton pigments in the western Mediterranean sea at the DYFAMED time-series station (1991-1999). Deep-Sea Res 49:1965-1985

McCave IN (1984) Size spectra and aggregation of suspended particles in the deep sea. Deep-Sea Res 31:329-352

Minas H, Minas M, Coste B, Gostan J, Nival P, Bonin MC (1988) Production de base et de recyclage; une revue de la problématique en méditerranée. Oceanol Acta 9:155-162

Miquel JC, La Rosa M (1999) Suivi à long terme des flux particulaires au site DYFAMED (Mer Ligure, Méditerranée occidentale). Océanis 25(2):303-308

Miquel J, Fowler S, La Rosa J, Buat-Menard P (1994) Dynamics of the downward flux of particles and carbon in the open northwestern Mediterranean Sea. Deep-Sea Res 41: 243-261

Moutin T, Raimbault P, Poggiale JC (1999) Primary production in surface waters of the western Mediterranean sea. Calculation of daily production. CR Acad Sci Paris Life Sci 322:651-659

Myklestad S (1977) Production of carbohydrates by marine planktonic diatoms. II. Influence of the N:P ratio in the growth medium on the assimilation ratio, growth rate, and production of cellular and extracellular carbohydrates by Chaetoceros affinis var. willei (Gran) Hustedt and Skeletonema costatum (Grev.) Cleve. J Exp Mar Biol Ecol 29: 161-179

Nival P, Corre MC (1976) Variations annuelles des caractéristiques hydrologiques de surface dans la rade de Villefranche-sur-mer. Ann Inst Oceanogr 52:57-78

Obernosterer I, Herndl GJ (1995) Phytoplankton extracellular release and bacterial growth: dependance on the inorganic N:P ratio. Mar Ecol Prog Ser 116:247-257

Passow U (2000) Formation of transparent exopolymeric particles, TEP, from dissolved precursor material. Mar Ecol Prog Ser 192:1-11

Passow U (2002) Transparent exopolymer particles (TEP) in aquatic environments. Prog Oceanogr 55:287-333

Passow U, Alldredge AL (1994) Distribution, size and bacterial colonization of transparent exopolymer particles (TEP) in the ocean. Mar Ecol Prog Ser 113:185-198

Passow U, Alldredge AL (1999) Do transparent exopolymeric particles (TEP) inhibit grazing by the euphausiid Euphausia pacifica? J Plankton Res 21:2203-2217

Passow U, Shipe RF, Murray A, Pak DK, Brzezinski MA, Alldredge AL (2001) The origin of transparent exopolymeric particles (TEP) and their role in the sedimentation of particulate matter. Cont Shelf Res 21:327-346
Penna A, Berlutti S, Penna N, Magnani M (1999) Influence of nutrient ratios on the in vitro extracellular polysaccharide production by marine diatoms from the Adriatic Sea. J Plankton Res 21:1681-1690

Ramaiah N, Yoshikawa TKF, Furuya K (2001) Temporal variations in transparent exopolymeric particles (TEP) associated with a diatom spring bloom in a subarctic ria in Japan. Mar Ecol Prog Ser 212:79-88

Redfield AC, Ketchum BH, Richards FA (1963) The influence of organisms on the composition of sea-water. In: Hill MN (ed) The sea, Vol 2. John Wiley \& Sons, New York, p 26-77

Sala MM, Peters F, Gasol JM, Pedros-Alio C, Marrasé C Vaqué D (2002) Seasonal and spatial variations in the nutrient limitation of bacterioplankton growth in the northwestern Mediterranean. Aquat Microb Ecol 27:47-56

Sambrotto RN, Savidge G, Robinson C, Boyd P and 6 others (1993) Elevated consumption of carbon relative to nitrogen in the surface ocean. Nature 363:248-250

Schuster S, Herndl GJ (1995) Formation and significance of transparent exopolymeric particles in the northern Adriatic Sea. Mar Ecol Prog Ser 124:227-236

Sheldon RW, Prakash A, Sutcliffe WH Jr (1972) The size distribution of particles in the ocean. Limnol Oceanogr 17: $327-340$

Smetacek VS (1985) Role of sinking in diatom life-history cycles: ecological, evolutionary and geological significance. Mar Biol 84:239-251

Sournia A, Brylinski JM, Dallot S, Le Corre P, Leveau M, Prieur L, Forget C (1990) Fronts hydrologiques au large des côtes françaises: les sites ateliers du programme Frontal. Oceanol Acta 9:119-131

Thingstad TF, Rassoulzadegan F (1995) Nutrient limitations, microbial food webs, and 'biological C-pumps': suggested interactions in a P-limited Mediterranean. Mar Ecol Prog Ser 117:299-306

Thingstad TF, Hagström ^, Rassoulzadegan F (1997) Accumulation of degradable DOC in surface waters: is it caused by a malfunctioning microbial loop? Limnol Oceanogr 42:398-404

Thingstad TF, Pérez M, Pelegri S, Dolan J, Rassoulzadegan F (1999) Trophic control of bacterial growth in microcosms containing a natural community from northwest Mediterranean surface waters. Aquat Microb Ecol 18:145-156

Toggweiler JR (1993) Carbon overconsumption. Nature 363: 210-211

Tréguer P, Le Corre P (1975) Manuel d'analyse des sels nutritifs dans l'eau de mer (utilisation de l'AutoAnalyzer Technicon), 2nd edn. Univ de Bretagne Occidentale, Brest

Van Wambeke F, Christaki U, Giannakourou A, Moutin T, Souvemerzoglou K (2002) Longitudinal and vertical trends of bacterial limitation by phosphorus and carbon in the Mediterranean Sea. Microb Ecol 43:119-133

Vidussi F, Claustre H, Bustillos-Guzman J, Cailliau C, Marty J (1996) Determination of chlorophylls and carotenoids of marine phytoplankton: separation of chlorophyll a from divinyl-chlorophyll $a$ and zeaxanthin from luthein. J Plankton Res 18:2377-2382

Wells ML (1998) Marine colloids - a neglected dimension. Nature 391:530-531

Williams PJL (1995) Evidence for the seasonal accumulation of carbon-rich dissolved organic material, its scale in comparison with changes in particulate material and the consequential effect on net C:N assimilation ratios. Mar Chem 51:17-29

Zweifel UI, Norrman B, Hagström $\AA$ (1993) Consumption of dissolved organic carbon by marine bacteria and demand for inorganic nutrients. Mar Ecol Prog Ser 101:23-32 